\title{
The Effects of Working Capital Management on Profitability of Manufacturing Companies: The Case of Dire Dawa City
}

\author{
Abel Mesfin Girma \\ Department of Management, Jigjiga University, Jigjiga, Ethiopia \\ Email address: \\ metiabelm@gmail.com \\ To cite this article: \\ Abel Mesfin Girma. The Effects of Working Capital Management on Profitability of Manufacturing Companies: The Case of Dire Dawa \\ City. Science Journal of Business and Management. Vol. 7, No. 6, 2019, pp. 135-139. doi: 10.11648/j.sjbm.20190706.11
}

Received: July 30, 2019; Accepted: September 21, 2019; Published: November 27, 2019

\begin{abstract}
In every organization, corporate finance deals with three decisions: capital structure decisions, capital budgeting decision, and working capital management decisions. Among these three decisions, working capital management is recognized as an important concern of the financial manager. The study examines the effects of working capital management on profitability of manufacturing companies in Dire Dawa city and have the following research objectives: Examine the effect of number of days account receivable (NDAR) on profitability of manufacturing companies, Examine the effect of number of days inventories (NDI) on profitability of manufacturing firms, To investigate the effect of no of days account payable (NDAP) on profitability of manufacturing firms and Examine the effect of cash conversion cycle (CCC) on profitability of manufacturing firms. The research was quantitative that utilizes secondary data of companies from $2011-2015$ for sample of 14 companies to address the objectives. The study purposively selected Dire Dawa city this is because of the majority of the Eastern region industries found in this city. The secondary data was collected from different company's records about from audited balance sheet and income statement that was submitted to Ethiopian revenue and custom authority Dire Dawa branch and Dire Dawa Administration Revenue Authority for tax purpose. The result of the study shows that there is significantly negative relationship between number of date account receivable, number of day's inventory holding and company's profitability. The study reveals that there is no significant relationship between number of days account receivable and profitability. But cash conversion cycle has significant negative relationship with profitability. Moreover debt ratio has statistically negative relationship with company's profitability.
\end{abstract}

Keywords: Working Capital Management, Number of Days Account Receivable, Profitability

\section{Introduction}

\subsection{Background of the Study}

Working capital management (WCM) is the process of regulating and controlling current asset and current liabilities of a firm to ensure firm's objectives are met and healthy operation of the firms are take place. Working capital is considered as a part of a company's operating capital, referring to current assets such as cash at hand, cash on bank account, raw materials, work in progress, finished goods, account receivable, etc. The popular measure of working capital management is the cash conversion cycle, which is a time gap between the expenditure for the purchase of raw materials and the collection of sales of finished goods. To determine the firm's profitability, the finance manager also need to take into account the firms working capital management, which basically means managing the firm's current assets and current liabilities at satisfactory level [1]. Recent findings show that management of working capital can foster firms short term assets and liabilities control that increases firms profitability [2]. The management of working capital involves managing inventories, account receivable, account payable and cash.

Firms that want to maximize their value have an optimal level of working capital and evaluate the trade-off between risk involved with making changes in working capital levels and the profitability they expect. Companies must retain an appropriate level of working capital to maximize their value. In other words, retention of high inventory levels and too much utilization of credit policies increase sales [3]. High levels of inventory reduces risk of depletion whiles credit 
policies initiate sales; mainly due to the fact that they allow the customer to evaluate the product prior to purchase [4]. For managers of firms there are two main objectives concerning the management of their firms [5]. First they want to maximize the Profitability of the firm, maximizing the value for the shareholders of the firm. Second they want to minimize the liquidity risk of the firm. Firms can attain maximum profit by reducing their cash conversion cycle and by strongly managing their AR [6].

Liquidity risk is the risk that firms do not have enough cash or other short-term assets to satisfy their financial obligations, which can cause Difficulties for firms in maintaining their corporate activities. Research conducted on Profitability versus risk trade-off reflects both the management of working capital, which Consists of shortterm assets, and the corporate decisions concerning long-term profitability Targets for firms. In short this trade-off suggests that when managers manage their working Capital efficiently they have less cash stocked in the firm, which can then be paid out to the Shareholders increasing their wealth [5].

In Ethiopia there is a little work on working capital management which may restrict the knowledge scope of financial managers and policy makers.

In this study to assess the efficiency of working capital management of companies, components like cash conversion cycle, account receivable period, inventory holding period, account payable period together with controlling variables like firm size, current ratio debt ratio and sales growth are used to examine the effect of working capital management on profitability of manufacturing companies in Dire Dawa city.

\subsection{Research Objectives}

The following are research objectives of the study:

i. Examine the effect of number of days account receivable (NDAR) on profitability of manufacturing companies.

ii. Examine the effect of number of days inventories (NDI) on profitability of manufacturing firms.

iii. To investigate the effect of no of days account payable (NDAP) on profitability of manufacturing firms.

iv. Examine the effect of cash conversion cycle (CCC) on profitability of manufacturing firms.

\subsection{Significance of the Study}

As we have noticed above there is little study on this area in our country especially in eastern part of Ethiopia so this study help companies to identify the important driving forces that enhance the profitability of their companies. In addition this research gives insight for those who conduct research in this area.

\subsection{Hypothesis of the Study}

The following hypothesis were developed to meet the objectives above

H1o: There is no significant relationship between number of days account receivable (NDAR) and profitability of companies.

H1a: There is significant relationship between number of days account receivable (NDAR) and profitability of companies.
H2o: There is no significant relationship between number of day's inventory holding (NDI) and profitability of companies.

$\mathrm{H} 2 \mathrm{a}$ : There is significant relationship between number of day's inventory holding (NDI) and profitability of companies.

H3o: There is no significant relationship between number of days account payable (NDAP) and profitability companies.

H3a: There is a significant relationship between number of days account payable (NDAP) and profitability of companies.

$\mathrm{H} 4 \mathrm{o}$ : There is no significant relationship between cash conversion cycle (CCC) and profitability of companies.

$\mathrm{H} 4 \mathrm{a}$ : There is significant relationship between cash conversion cycle (CCC) and profitability of companies.

\section{Research Methodology}

The study aimed at determining the effects of working capital management on profitability of manufacturing companies in Dire Dawa city for a period covering from 2011 to 2015. The study used explanatory research along with quantitative method to meet the objectives of the study. The casual relationship between different variables was identified and evaluated by using explanatory types of research [7]. For the attainment of research objective the researcher used the audited financial report of selected manufacturing companies. The data was collected from Ethiopian Revenue and Custom Authority Dire Dawa Branch and Dire Dawa Administration Revenue Authority. The population of the study consists of manufacturing companies which are found in Dire Dawa city and registered Dire Dawa administration trade, industry and investment bureau. The sample size that was selected was considered as best to represent the whole population and make finding precise and confidential. So from the total of 54 manufacturing companies who have audited financial report 14 companies with 70 observations were selected. The reason for selecting these 14 manufacturing companies is due to their complete financial data of stated year and accessible. The sampling technique of the study was non-probability sampling technique; from this purposive sampling technique was used. The reason for using this sampling lies in that the firms selected in the sample must fulfill the required financial data for the period of 2011-2015. The results of the collected data from the above sample were organized, analyzed and interpreted in sensible way. The collected data was analyzed by using STATA 12 software. The study used descriptive statistics for describing the collected sample and used linear Regression analysis to see the association between working capital management and manufacturing firm's profitability.

The model specification of the study was extended from model developed [15].

The general model for the study was as follows:

$$
\mathrm{Yi}=\beta 0+\Sigma \beta \mathrm{iXi}+\varepsilon \mathrm{i}
$$

Where:

$\mathrm{Yi}=$ the ith observation of dependent variable

$\beta 0=$ the intercept of the equation

$\beta \mathrm{i}=$ coefficients of $\mathrm{X} \mathrm{i}$ variables 
$\mathrm{Xi}=$ the different independent variables

$\varepsilon i=$ the error term
The specific model of each variable is as follows:

The effect of NDAR on profitability of firms

$$
\text { GOPi, } \mathrm{t}=\text { GOPi, } \mathrm{t}=\beta 0+\beta 1 \text { NDARi, } \mathrm{t}+\beta 2 \text { CRi, } \mathrm{t}+\beta 3 \text { F. SIZEi, } \mathrm{t}+\beta 4 \mathrm{~S} . \mathrm{Gi}, \mathrm{t}+\beta 5 \mathrm{DR} i, \mathrm{t}+\varepsilon \mathrm{i}, \mathrm{t}
$$

The effect of NDI on profitability of firms

$$
\text { GOPi, } \mathrm{t}=\beta 0+\beta 1 \text { NDIi, } \mathrm{t}+\beta 2 \mathrm{CRi}, \mathrm{t}+\beta 3 \mathrm{~F} \text {. SIZEi, } \mathrm{t}+\beta 4 \mathrm{~S} \text {. Gi, } \mathrm{t}+\beta 5 \mathrm{DR} i, \mathrm{t}+\varepsilon \mathrm{i}, \mathrm{t}
$$

The effect of NDAP on profitability of firms

$$
\text { GOPi, } \mathrm{t}=\beta 0+\beta 1 \text { NDAPi, } \mathrm{t}+\beta 2 \mathrm{CRi}, \mathrm{t}+\beta 3 \mathrm{~F} \text {. SIZEi, } \mathrm{t}+\beta 4 \mathrm{~S} . \mathrm{Gi}, \mathrm{t}+\beta 5 \mathrm{DR} i, \mathrm{t}+\varepsilon \mathrm{i}, \mathrm{t}
$$

The effect of CCC on profitability of firms

$$
\text { GOPi, } t=\beta 0+\beta 1 C C C i, t+\beta 2 C R i, t+\beta 3 F . \text { SIZEi, } t+\beta 4 S . \text { Gi, } t+\beta 5 D R i, t+\varepsilon i, t
$$

Where profitability of the firms refer to GOP, while $i$ stands for the ith firm, $t$ stands for year $t$, and the variables are defined as follows:-

GOPi, t: Gross Operating Profit of firm i at time $t$

NDAR i, t: Number of days Accounts Receivable of firm i at time $\mathrm{t}$

NDI $i, t$ : Number of days Inventories of firm $i$ at time $t$

NDAP $i, t$ : Number of days Accounts Payable of firm $i$ at time $t$

$\mathrm{CCC}$ i, $\mathrm{t}$ : Cash Conversion Cycle of firm i at time $\mathrm{t}$

CR i, t: Current Ratio of firm $i$ at time $t$

F. SIZE i, t: Firm Size of firm i at time $t$
S. G i, t: Sales Growth of firm i at time $t$

DR i, $t$ : Debt ratio of firm $i$ at time $t$

$\beta 0$ : Intercept coefficient

ci, t: Time varying disturbance term serially uncorrelated with mean zero and variance 1 . Random error term for firm $i$ at time $t$

\section{Result and Discussion}

The following part shows descriptive statistics for Dire Dawa city manufacturing companies for a period of 5 years from 2011 - 2015 on 70 observations.

Table 1. Summary of Descriptive Statistics.

\begin{tabular}{llllll}
\hline Variables & observation & Min & max & Mean & Std. Dev. \\
\hline GOP & 70 & -.405 & .381 & .098 & .192 \\
NDAR & 70 & 55.59 & 123.622 & 93.411 & 16.22 \\
IHP & 70 & 87.72 & 139.068 & 119.254 & 12.5 \\
NDAP & 70 & 39.25 & 98 & 77.21 & 11.923 \\
CCC & 70 & 59.88 & 117.537 & 92.949 & 14.752 \\
F. SIZE & 70 & 5.632 & 21.694 & 15.929 & 3.383 \\
CR & 70 & .0595 & .756 & .4197 & .172 \\
DR & 70 & .557 & 1.492 & 1.183 & .180 \\
S. GROWTH & 70 & .0589 & .688 & .429 & .161 \\
\hline
\end{tabular}

Source: STATA 12 output from financial statement of sample companies 2011-2015

Table 1 indicates the average profit of manufacturing companies which is represented by GOP is $9.8 \%$. The above table also indicates the minimum and maximum value for GOP is $-40.5 \%$ and $38.1 \%$ respectively. Further the standard deviation of GOP is 19.2 which implies the profit level or the value of GOP can increase or decrease from the mean value by $19.2 \%$.

As one component of working capital management inventory holding period has an average value of 119 days with standard deviation of 13 days. The maximum values that companies hold their inventory to convert it to sales was 139 days and the minimum value is 88 days. Company's stay an average of 93 days with standard deviation of 16 days to collect their credit sales. The minimum and maximum value of number of days account receivable is 56 and 124 days respectively. For companies to undertake their overall activities they need an average of 93 days with 15 days of standard deviation. The cash conversion cycle have minimum of 60 days and maximum of 118 days an average of 77 days is required for companies to repay back their credit purchase from their suppliers with standard deviation of 12 days. The minimum and maximum values for companies to repay their credit purchase were 39 and 77 respectively.

Firm size was one of control variables with average value of 16 and standard deviation of 3 . The minimum value of firm size was 5.6 and 21.6.

The control variable was current ratio which indicates the liquidity position of a company with an average value of 41.97 percent with standard deviation of 17.2 percent. The minimum value for current ratio was 0.059 and the maximum value was 0.756 .

The average value for debt ratio was 1.18 with a standard deviation of 0.18 . The minimum and maximum values for debt ratio were 0.55 and 1.49 respectively.

The last control variables of the study were sales growth with an average value of 42.9 percent and standard deviation of 16.1 percent. The minimum value for sales growth was 5.8 percent and maximum value was 68.8 percent. 


\subsection{Correlation Analysis}

Correlation analysis is conducted to check if there is an association between variables before running of regression $[8,9]$.
But correlation analysis has a short coming of identifying a cause and effect relationship variables [8]. The following table shows the summary of correlation analysis.

Table 2. Correlation Matrix.

\begin{tabular}{|c|c|c|c|c|c|c|c|c|c|}
\hline & GOP & NDAR & NDI & NDAP & $\mathrm{CCC}$ & F. SIZE & CR & DR & S. GROWTH \\
\hline GOP & 1.0000 & & & & & & & & \\
\hline NDAR & -0.9897 & 1.0000 & & & & & & & \\
\hline NDI & -0.2401 & 0.2135 & 1.0000 & & & & & & \\
\hline NDAP & -0.9894 & 0.9846 & 0.2149 & 1.0000 & & & & & \\
\hline $\mathrm{CCC}$ & -0.9849 & 0.9899 & 0.2372 & 0.9823 & 1.0000 & & & & \\
\hline F. SIZE & 0.1495 & -0.1226 & -0.1311 & -0.1390 & -0.1439 & 1.0000 & & & \\
\hline $\mathrm{CR}$ & -0.0894 & 0.0960 & -0.0090 & 0.0910 & 0.0665 & 0.0232 & 1.0000 & & \\
\hline S. GROWTH & 0.0708 & -0.0652 & 0.0904 & -0.0651 & -0.0218 & 0.1438 & -0.0103 & 0.1027 & 1.0000 \\
\hline
\end{tabular}

Correlation is significant at $5 \%$

Source: STATA 12 output from financial statement of sample companies 2011-2015

Table 2 indicates there is high level of correlation exists between NDAP and NDAR which is 98.4 percent and also between CCC and NDAP which is 98.2 percent and between CCC and NDAR which is 98.9 percent. So the study cannot regress into one linear regression with the presence of all independent variable due to the presence of high correlation
$[10,11]$.

The study avoided the variables that are highly correlated and developed four regression model that regress the four components of working capital management individually with control variables.

Table 3. Fixed Effect mode linear Regression Result of Effects of Working Capital Management on profitability. Dependent Variable Gross Operating Profit $(G O P)$.

\begin{tabular}{|c|c|c|c|c|}
\hline Model & I & II & III & IV \\
\hline CONS. & $3.75(.9701)$ & $5.04(1.6166)$ & $2.91(.8249)$ & $4.73(1.2951)$ \\
\hline NDAR & $-2.25(-.0048)$ & & & \\
\hline NDI & & $-3.85(-.0081)$ & & \\
\hline NDAP & & & $-1.01(-.0020)$ & \\
\hline $\mathrm{CCC}$ & & & & $-3.52(-.0066)$ \\
\hline F. SIZE & $2.14(.0148)$ & $2.24(.0143)$ & $1.45(.0113)$ & $0.62(.0044)$ \\
\hline $\mathrm{CR}$ & $0.50(.1169)$ & $0.86(.1830)$ & $-0.38(-.0922)$ & $-0.03(-.0069)$ \\
\hline SG & $-0.63(-.1261)$ & $-1.34(-.2536)$ & $-0.27(-.0563)$ & $-0.23(-.0404)$ \\
\hline R-square & 0.9955 & 0.9962 & 0.9952 & 0.996 \\
\hline Adjusted R-square & 0.9939 & 0.9948 & 0.9935 & 0.9946 \\
\hline $\mathrm{F}-$ static & 59.27 & 71.37 & 54.24 & 68.30 \\
\hline Hausman Test (Chi-sq. static) & 15.99 & 63.33 & 9.98 & 20.64 \\
\hline
\end{tabular}

Significant level at $95 \%$

Source: STATA 12 output from financial statement of sample companies 2011-2015

Table 3 from model I it was observed that there exist significant negative relationship between NDAR and GOP at 5 percent significant level. The study states that a one day increases in NDAR reduce the profit by $-0.48 \%$.

The output of Table 3 states that the adjusted R-square of the model was 0.99 percent this indicates $99 \%$ variation in GOP is explained by the variable in the model. The result of F-statistic of the model shows that 59.27 at $p$ value of 0.0000 . The result of the study was consistent with other studies that show the existence of negative relationship between NDAR and profitability $[12,13]$. Model II on table 3 shows that there is statistically negative relationship between NDI and GOP at 5 percent significance level. According to the study a one day increase in NDI has decreases profit by -0.81 . The adjusted R-square of the model is 99 percent which is explained as the variation in GOP is 99 percent explained by
NDI other thing remains constant. The F-static of the model was 71.37 with p-value of 0.0000 .

The finding of the study was supported by previous studies $[3,12]$.

From model III on Table 3 it was predicted that there is no statistically significant relationship between NDAP and GOP. According to the finding a one day delay in NDAP decreases the profit by 0.2 percent. Other thing remain constant the change in GOP is 99 percent explained by NDAP but the variable was statistically insignificant. The F-statics of the model was 54.24 with p-value of 0.000 .

The study was contrary with other results [1]. And the result was supported by studies made [3, 13].

Model IV of table 3 shows there exist significant negative relationship between $\mathrm{CCC}$ and GOP at 5 percent significance level. The study suggests that by increasing the CCC the 
profit or (GOP) was reduced by- 0.66 percent. The R-square of the model was $99.6 \%$ change in GOP is explained by CCC other things remained constant. The F-static of the model was 68.3 with $p$-value of 0.0000 .

The study was supported by previous studies conducted by $[3,5,13,14]$.

\section{Conclusion}

The study focused on finding out the effect working capital management on company's profitability case study on Dire Dawa city. For conducting of the study the researcher utilized secondary data of five years from 2011 - 2015 on samples of 14 manufacturing companies. The study also used purposive sampling technique and the researcher selected this method of sampling based on pre-determined criteria like for companies that have five year balance sheet and income statement and easy to access their data. For the purpose of estimating the data fixed effect model were used. The study has one dependent variable which is gross operating profit (GOP) and eight independent variables. Among these eight variables four are components of working capital management which are number of days account receivable, number of day's inventory holding, number of days account payable and cash conversion cycle. The remaining four variables were control variables and they are firm size, current ratio, debt ratio and cash conversion cycle.

\section{Recommendation}

i. The manufacturing companies must conduct tight collection policy of credit provided by them for their customers since there exist significant negative relationship between number of days account receivable and gross operating profit. Companies must give a care when they inject tight credit policy toward their customers in such a way that they must keep account receivable days at optimum level without dissatisfying their customers.

ii. The number of day's inventory holding has significant negative relationship with profitability of companies. So companies must give due attention for their inventory holding periods since it has inverse implication on their profitability. In other words detaining of inventory has high associating costs that increase cash outflow. So managers must develop market strategy to detect the market demand to produce in line with that market demand so as to reduce the duration of holding inventory.

iii.Lastly the negative relationship between the cash conversion cycle and gross operating profit indicates negative impact on company's profitability. So the study suggests managers to minimize their cash conversion cycle at optimum level.

\section{References}

[1] Dong, H. P. and Su, J. T., 2010. The Relationship between Working Capital Management and Profitability: A Vietnam case, International Research Journal of Finance and Economics, Issue No. 49, pp. 59-67.

[2] Dalayeen, A. B. (2017). Working capital management and profitability of the real estate industry in Jordan. An empirical study. Journal of Applied Finance and Banking, 2 (2), 49-57. Deloof, M., 2003.

[3] Does Working Capital Management Affect Profitability of Belgian firms? Journal of Business Finance \& Accounting, 30 (3 \& 4) pp. 573-588.

[4] Petersen, M. A. and Rajan R. G., 2007. Trade credit: theories and evidence: Review of Financial Studies, 10 (3) pp. 661-691.

[5] Tewodros A, 2010. The Effect of Management of Working Capital Policies on Firms Profitability. Evidence from Manufacturing Private Limited Companies in Tigray region, Ethiopia.

[6] Bibi, N., \& Amjad, S. (2017). The relationship between liquidity and firm's profitability: A case study of Karachi Stock exchange. Asian Journal of Finance and Accounting, 9 (1), 54-66.

[7] Creswell, J. W., 2002. Research Design: Qualitative, Quantitative, and Mixed Methods Approaches 2nd ed. SAGE publications. inc.

[8] Padachi, K., 2006. Trends in Working Capital Management and its Impact on Firms' Performance: An Analysis of Mauritian Small Manufacturing Firms, International Review of Business Research Papers, 2 (2) pp. 45-58.

[9] Zariyawati, M. A., Annuar, M. N., Taufiq, H. and Abdul Rahim, A. S., 2009. Working Capital Management and Corporate Performance: Case of Malaysia, Journal of Modern Accounting and Auditing, 5 (11) pp. 47-54

[10] Pallant, J. F., 2009. SPSS Survival Manual, 3rd Ed, Sydney: Ligare Book Printer.

[11] Reimann, C., Filzmoser, P., Garrett, R. G. and Dutter, R., 2008. Statistical Data Analysis Explained. Applied Environmental Statistics with R. John Wiley \& Sons Ltd.

[12] Falope, O. I. and Ajilore, O. T., 2009. Working Capital Management and Corporate Profitability: Evidence from Panel Data Analysis of Selected Quoted Companies in Nigeria, Research Journal of Business Management, 3 (3) pp. 73-84.

[13] Mulualem, M., 2011. The Impact of Working Capital Management on Firm's Profitability in Selected A. A Manufacturing Share Companies, (Unpublished Msc) Addis Ababa University: School of Public and Business Administration.

[14] Lazaridis, I. and Tryfonidis, D., 2006. Relationship between working capital management and profitability of listed companies in the Athens Stock Exchange, Journal of Financial Management \& Analysis, 19 (1) pp. 26-35.

[15] Sharma, A. K. and Kumar, S., 2011. Effect of Working Capital Management on Firm Profitability: Empirical Evidence from India, Global Business Review, 12 (1) pp. 159-173. 